\title{
Family Dynamics and Well-Being among Rural Communities in Malaysia During Covid-19 Pandemic
}

Nellie Ismail, Rumaya Juhari, Zainal Madon, Mariani Mansor, Rojanah Kahar, Muslihah Hasbullah, Mohd Najmi Daud, Nellie Ismail, Mohamad Naqiuddin Dahamat Azam

To Link this Article: http://dx.doi.org/10.6007/IJARBSS/v11-i11/11649 DOI:10.6007/IJARBSS/v11-i11/11649

Received: 04 September 2021, Revised: 10 October 2021, Accepted: 29 October 2021

Published Online: 20 November 2021

In-Text Citation: (Ismail et al., 2021)

To Cite this Article: Ismail, N., Juhari, R., Madon, Z., Mansor, M., Kahar, R., Hasbullah, M., Daud, M. N., Ismail, N., \& Azam, M. N. D. (2021). Family Dynamics and Well-Being among Rural Communities in Malaysia During Covid-19 Pandemic. International Journal of Academic Research in Business and Social Sciences, 11(11), 1610-1623.

Copyright: (c) 2021 The Author(s)

Published by Human Resource Management Academic Research Society (www.hrmars.com) This article is published under the Creative Commons Attribution (CC BY 4.0) license. Anyone may reproduce, distribute, translate and create derivative works of this article (for both commercial and non0-commercial purposes), subject to full attribution to the original publication and authors. The full terms of this license may be seen at: http://creativecommons.org/licences/by/4.0/legalcode

Vol. 11, No. 11, 2021, Pg. $1610-1623$

Full Terms \& Conditions of access and use can be found at http://hrmars.com/index.php/pages/detail/publication-ethics 


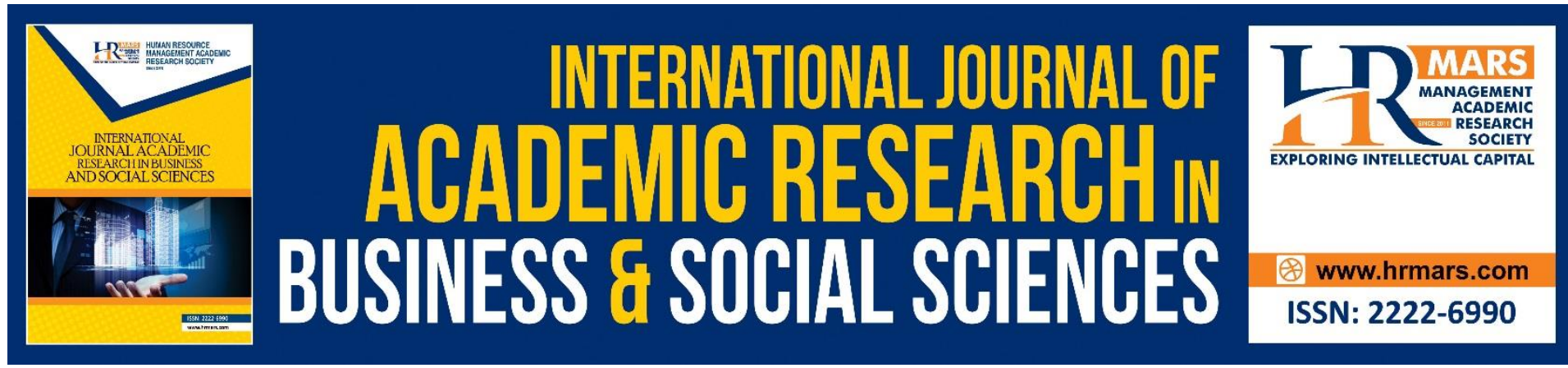

\title{
Family Dynamics and Well-Being among Rural Communities in Malaysia During Covid-19 Pandemic
}

\author{
Nellie Ismail, Rumaya Juhari, Zainal Madon, Mariani Mansor, \\ Rojanah Kahar, Muslihah Hasbullah, Mohd Najmi Daud, Nellie \\ Ismail, Mohamad Naqiuddin Dahamat Azam \\ Department of Human Development \& Family Studies, Faculty of Human Ecology, \\ Universiti Putra Malaysia, 43400 Serdang, Selangor. \\ Email:nellie@upm.edu.my
}

\begin{abstract}
The Coronavirus Disease 2019 (COVID-19) pandemic currently faced worldwide does not only negatively impact the aspects of physical health and national economies but also on one's well-being. Such effect is felt by communities living in urban and rural areas alike, without compromise. Therefore, the objective of this study was to determine the relationship between the determinants of family dynamics (i.e., family relationships, family conflict, social support, financial stress, and stress) and well-being among rural communities in Malaysia during the pandemic. The data for this study were gathered from an online survey participated by 1,587 respondents from the Family and Community Empowerment Programme (FACE). To this end, a total of 916 respondents who were part of the rural communities in Malaysia were included in the present study. The findings revealed that family relationships and social support posed a significantly positive correlation with well-being. The results also showed that financial stress, family conflict and stress were significantly and negatively correlated with well-being. Meanwhile, multiple regression analysis outcomes indicated that family relationships yielded the strongest influence on well-being. In conclusion, healthy family relationships greatly influence an individual's well-being, especially in the context of rural communities in Malaysia during the Movement Control Order.
\end{abstract}

Keywords: COVID-19, Family Dynamics, Pandemic, Rural Community, Well-Being

\section{Introduction}

As of currently, the global COVID-19 outbreak has been declared by the World Health Organisation (WHO) as a pandemic as it affects almost all countries worldwide. Following this, its negative impact extends beyond physical health and economies as it further implicates individual well-being due to challenges related to social disruption, such as caregiving burden and financial problems (Prime, Wade \& Browne, 2020). In the bid to break the chain of infection and prevent healthcare system collapse, the Malaysian government-enforced Movement Control Order (MCO) on 18 March 2020, thus allowing the population to go out 
for important purposes only, such as purchasing food, acquiring medical care, and important work-related duties. According to Ratnasingam (2020), its implementation leads to substantial social and economic interruptions in combination with amplified society-wide concerns pertaining to MCO duration and its socio-economic and psychological consequences.

Individual well-being during MCO is typically impacted by several factors, including financial stress (Northern et al., 2010). For individuals, financial stress can arise from various factors such as poor budgeting or loss of employment. Reports have indicated that the number of people that had lost their jobs in Malaysia since the MCO first commenced in March increases every month (Malaysia Kini, 2020). Meanwhile, the survey by the Department of Statistics Malaysia (2020) has specifically revealed that about 33 per cent of workers in the fisheries and aquaculture sectors had lost their jobs due to the COVID-19 pandemic. Tangentially, Infurna and Luthhar (2016) have suggested that job loss is one of the life stressors that will require a long time for one to recover psychologically, whereby it may also cause financial stress and impact their well-being. Quarantines or lockdowns are necessary to protect physical health, but prolonged impositions may be detrimental. It is a hostile experience that can cause stress due to change in routine, separation from family members and friends, monetary issues and loss of independence. The study conducted by Thoits (2010) indicated that stress can further implicate the health and well-being of a person.

Another factor that can influence an individual's well-being is family relationships. Previous literature has shown that family relationships play a vital role in developing a person's wellbeing across the life span. However, data from the Ministry of Women, Family and Community Development (MWFCD) and Non-Governmental Organizations (NGOs) have revealed an increased number of domestic violence in Malaysia since MCO implementation (New Straits Time, 2020). Such a situation may be attributable to the varying challenges encountered by different family members during the period, following which adapting to the changes in routines and activities are deemed stressful for most people. Alternatively, the quality of social support is an important predictor of an individual's well-being (Lincoln, 2014), wherein those with strong social support might assist them in managing their stress (Landstedt, Hammarström, \& Winefield, 2015; Uchino, 2006). Besides, social support is not only important in minimising any negative symptoms as it can further enhance one's positive adaptation during the pandemic (Saltzman, Hansel \& Bordnick, 2020). Such elements will aid them in relieving any anxiety symptoms that they are experiencing in the face of stress (Jacobson, Lord \& Newman, 2017).

To date, most of the studies conducted in Malaysia have primarily concentrated on the effects of the COVID-19 pandemic on the national economy (Shakeel et al., 2020), environment (Nadzir et al., 2020; Muhammad et al., 2020), and mental health (Dai et al., 2020). Hence, this study aims to contribute to the existing literature by empirically evaluating the relationship between family dynamics and well-being in the context of Malaysian rural communities during the COVID-19 pandemic. 


\section{Objectives of the Study}

The main objective of this study is to determine the relationship between family dynamics and well-being among rural communities in Malaysia during the COVID-19 pandemic. Meanwhile, the specific objectives are as follows:

1. To describe the background of rural communities in Malaysia.

2. To determine the relationship between family dynamics (i.e., family relationships, family conflict, financial stress, social support, and stress) and well-being among rural communities in Malaysia.

3. To determine the unique predictors of well-being among rural communities in Malaysia.

\section{Literature Review \\ Well-being}

In general, well-being is a terminology that refers to how individuals experience and perceive their lives in a positive way (Tov, 2018). Accordingly, numerous studies have attempted to explain the conceptualisation; for instance, Ryan and Deci (2001) have categorised well-being into two major approaches, namely hedonic and eudaimonic. Definition-wise, hedonic wellbeing describes the pleasant feelings and satisfaction that one perceives with their life, whereas eudaimonic well-being delineates the development of individual strengths, virtuous living, and contribution to one's betterment. In contrast, well-being has been detailed by other researchers according to three main approaches, the first of which is emotional wellbeing (Diener et al., 2009) otherwise described as a feeling of happiness and life satisfaction. Meanwhile, the second approach is psychological well-being, which is defined as living a rich life in which one's abilities are taken into account, whereas the third approach of social wellbeing refers to how one values and feels valued by people around them (Diener et al., 2009).

\section{Family Dynamics}

The definition of family dynamics pertains to the pattern of interactions, roles, and relationships seen between relatives and the varying factors influencing such interactions (Jabbari \& Rouster, 2020). The current study categorises family dynamics into five factors: family relationships, family conflict, financial stress, social support and stress. The first factor of family relationships can be delineated by defining family itself, which is one of the social systems that may influence a person's development (Henry et al., 2015). This reflects how family members are an essential source of social connection and influence in one's life (Umberson, Crosnoe, \& Reczek, 2010). Besides, Merz and colleagues (2009) have suggested that family relationships play a vital role in nurturing individual well-being throughout their life span, whereby those supportive and secure nature will provide love, care, and advice. In contrast, stressful family relationships render one burdened with problems such as arguments, constant critical feedback, and onerous demands (Gunn \& Eberhardt, 2019).

Meanwhile, the second factor of family conflict refers to arguments, fights, abusive behaviour, and violence between partners or other family members within a home as defined by Habib and colleagues (2014). According to Marta and Alfieri (2004), it often involves opposition between family members, thus categorisable in different forms as follows: physical, verbal, financial, sexual, or psychological. Accordingly, a family conflict may involve a dispute between parents and children, between siblings, or within a couple (Marta \& Alfieri, 2014), as well as serving as an indication of family decline (Widmer, 2010). Next, the third 
factor of family dynamics is financial stress, which is described as the perceptions and emotional responses that one holds about their financial status (Prawitz et al., 2006). Alternatively, other researchers define it as an individual inability to fulfil their financial responsibilities, wherein it can be influenced by their beliefs, behaviour, and psychological factors (Northern et al., 2010). Moreover, Northern, O'Brien and Goetz (2010) have delineated financial stress as a person's inability to meet their financial obligations; however, this may also include emotional and psychological effects as it can influence different aspects of life, such as relationships and well-being.

Social support as the fourth factor is defined by Cohen (2004) as a social network that can provide emotional, informational, and instrumental resources, which is thus divided into two categories. Objective support as the first category encompasses direct financial support, social network presence, and relationship and participation among community members (Kaniasty \& Norris, 2018). Meanwhile, the second category is subjective support, thereby referring to one's understanding and respect of emotional experience and satisfaction. This form of support is also closely linked with the subjective feeling held by an individual (Kaniasty \& Norris, 2018). Prior research works have thus indicated social support as one of the essential factors possibly influencing their subjective well-being (Helliwell, Layard, \& Sachs, 2016). Similarly, Siedlecki, Salthouse, Oishi, and Jeswani (2014) have substantiated such a notion via their study, which has depicted a significant and positive relationship between social support and life satisfaction.

The fifth and last factor is stress. Davis and Mantler (2004) have described this factor as an unpleasant feeling experienced by an individual when they perceive that something of value is lost or being threatened. Such loss or threat may be material, social, or economic in nature. Additionally, prior research works have indicated that personal factors such as economic and family problems are a source of individual stress (Robbins, Judge \& Vohra, 2013). The work of Manita, Mawarpury, Khairani, and Sari (2019) has underlined that stress poses a significant and negative relationship with well-being accordingly.

\section{Theoretical Perspective}

\section{PERMA Model}

The current study adopts the PERMA model of well-being (Seligman, 2011) as a theoretical framework to determine the relationship between family dynamics and well-being among rural communities in Malaysia. It consists of five domains related to well-being, namely: positive emotion $(P)$, engagement $(E)$, relationships $(R)$, meaning $(M)$, and accomplishment (A). According to Seligman (2011), the model is capable of delineating how one can undertake positive actions within each domain to increase their well-being. The first domain of positive emotions refers to pleasant feelings such as pleasure, joy, and contentment, whereas the engagement domain describes the psychological connection (e.g. feeling interested, absorbed, and engaged) that one holds to any particular activities or organisations.

Furthermore, relationships as the third domain encompass the feeling of connection one perceives with others, wherein a positive relationship entails one feeling socially integrated, cared for, and supported by others and satisfied with their social network. Previous researchers have indicated that support from social relationships may lead to reduced depression levels and enhanced physical health (Perissinotto et al., 2012). Next, the fourth 
domain of meaning is described as having a goal or mission in life and feeling connected to something greater than oneself. In line with this, people with meaning in their lives are more likely to feel happy and satisfied as a whole (Baumeister et al., 2013). The fifth and last domain in the PERMA model is an accomplishment, thereby referring to one's progression towards their target, perceived sense of accomplishment, and feeling capable of carrying out daily routines.

\section{Materials and Methods Research Design}

This study employed a quantitative online survey methodology with a correlational design to gather information regarding the relationship between family dynamics and well-being perceived by the Malaysian rural communities. The survey was designed and thus disseminated in the Google Forms application.

\section{Population and Sampling Procedures}

The data for this study were gathered from an online survey participated by 1,587 respondents from the Family and Community Empowerment Programme (FACE) carried out by National Population and Family Development Board (NPFDB). To this end, a total of 916 respondents who were part of the rural communities in Malaysia were included in the present study. The sample of this study was recruited from five rural areas which involved residential area, land settlement, fishermen's village, traditional village and people housing programme. These locations were selected by using the random cluster sampling technique. Only respondents who had access to the Internet were able to participate in the study.

\section{Data Collection}

This study was formally approved by the Ethics Committee for Research Involving Human Subjects, Universiti Putra Malaysia (JKEUPM-2020-158). Data collection was carried out via an online survey disseminated in the Google Forms application and conducted in May 2020. A link containing the Google Forms survey was sent to all respondents through the WhatsApp application, whereby they were provided with informed consent prior to online survey completion.

\section{Pilot Study}

A pilot test was conducted to determine the reliability of the instruments. According to Mikuska (2017), by implementing the instruments to at least 12 to 50 people before the actual research will allow researchers to identify the strengths and weakness of the instrument, ready for any necessary modifications. Hence, 20 respondents from the FACE community in Selangor were selected for the pilot study. The data collected were tested by using SPSS software to analyse the reliability of the instruments. Based on the results of the pilot study, it showed that the instruments are considered reliable.

\section{Variables and Measurements}

Individual well-being was measured in this study by using the Personal Well-being IndexAdult (Cummins, 2013). The scale comprised seven items such as standard of living, health, life achievement, personal relationships, personal safety, community connectedness, and future security to measure respondent satisfaction. Each item was rated on a 10-point Likert scale ranging from 0 ('No satisfaction at all') to 10 ('Completely satisfied'), whereby a higher 
total score was indicative of higher levels of well-being. In the current study, the scale yielded a good reliability score as per its Cronbach's Alpha coefficient of .93.

The five factors of family dynamics were assessed in the current study to achieve its objective, namely family relationships, family conflict, social support, financial stress, and stress. Here, the scale for family relationships was developed by the researchers based on previous studies, thereby consisting of five items rated on a 5-point Likert scale ranging from 1 ('Never') to 5 ('Always'). Higher scores would indicate better family relationships, following which the internal consistency was recorded as .85 . Meanwhile, the scale for family conflict was developed by the researchers according to previous studies, thus encompassing three items rated on a 5-point Likert scale ranging from 1 ('Never') to 5 ('Always'). Higher scores would indicate a higher level of family conflict, wherein the scale yielded a reliability coefficient of .67. Next, the scale for financial stress was developed by the researchers based on previous studies and included four items rated on a 5-point Likert scale ranging from 1 ('Never') to 5 ('Always'). A higher score would suggest a higher level of financial stress, whereby the internal consistency of the scale was found to be .85 .

For the social support factor, the scale was developed by the researchers based on previous studies, comprising five items rated on a 5-point Likert scale ranging from 1 ('Never') to 5 ('Always'). Here, a higher score would be suggestive of a higher social support level, following which its Cronbach's Alpha value of .61. Meanwhile, the scale for stress factor was developed by the researchers by using the Perceived Stress Scale (PSS) (Cohen et al., 1983) and Depression Anxiety Stress Scales (DASS) (Lovibond \& Lovibond, 1995). The instruments need to undergo certain modifications to suit the objective and goals of the actual study. Hence, the instruments have been updated to 5-point Likert scale ranging from 1 ('Never') to 5 ('Always'). A higher score indicated a higher level of stress and the resulting Cronbach's Alpha value was .85 .

The developed instruments in this study were validated by expert panels in related fields. They were requested to provide their expert opinions to improve the content validity of the developed instruments. Content validity usually involves reviewing a new survey instrument to ensure that it contains all the necessary items and excludes undesirable items from a specific construction domain (Lewis et al., 1995, Boudreau et al., 2001). After acquiring the expert feedback, the instruments were revised accordingly.

\section{Data Analysis}

The collected data were subjected to an analysis by using SPSS version 25, while descriptive statistics were performed to describe the background of rural communities found in Malaysia. Next, an analysis of Pearson's correlation was utilised to determine the relationship between different factors of family dynamics (i.e. family relationships, family conflict, financial stress, social support, and stress) and the well-being of Malaysian rural communities. This was followed by a multiple regression analysis, which served to identify the unique predictors of well-being among said rural communities. 


\section{Results}

\section{Descriptive Analysis}

Table 1 reveals that most of the respondents (33\%) come from residential areas, while the remaining population are from land settlements (28.5\%), fishermen villages $(22.3 \%)$, traditional villages (15.7\%), and the People's Housing Programme (PPR) (0.5\%). Gender-wise, more than half (52\%) of them were male, whereas the latter $48 \%$ were female respondents. In terms of age, $40 \%$ of the respondents were between $35-60$ years old, while a majority (73.8\%) of the sample size was of Malay descent. Meanwhile, majority $(79.6 \%)$ of the respondents were married.

Table 1: Distribution of Respondent's Background ( $\mathrm{N}=916)$

\begin{tabular}{ll}
\hline Variables & $\mathbf{N}(\%)$ \\
\hline Types of communities & \\
$\quad$ Residential area & $302(33.0 \%)$ \\
$\quad$ Land settlements & $261(28.5 \%)$ \\
$\quad$ Fishermen's village & $204(22.3 \%)$ \\
$\quad$ Traditional village & $144(15.7 \%)$ \\
$\quad$ People's Housing Programme (PPR) & $5(0.5 \%)$ \\
Gender & \\
$\quad$ Male & $479(52.3 \%)$ \\
Female & $437(47.7 \%)$ \\
Age $\quad$ & \\
18-25 years old & $58(6.3 \%)$ \\
26-35 years old & $130(14.2 \%)$ \\
36-60 years old & $599(65.4 \%)$ \\
>60 years old & $129(14.1 \%)$ \\
Race & \\
Malay & $676(73.8 \%)$ \\
$\quad$ Chinese & $4(0.4 \%)$ \\
Indian & $4(0.4 \%)$ \\
Sabahans & $215(23.5 \%)$ \\
Others & $5(0.5 \%)$ \\
Marital status & $12(1.3 \%)$ \\
Married & \\
Single & \\
Divorced & \\
$\quad$ Widowed & $729(79.6 \%)$ \\
\hline
\end{tabular}

\section{Family Dynamics and Well-Being}

The relationship between family dynamics (i.e. family relationships, family conflict, financial stress, social support, and stress) and well-being was analysed in this study by using Pearson's correlation. Accordingly, family relationships $(r=.509 * *, p \leq 0.01)$ and social support $(r=$ $.361^{* *}, p \leq 0.01$ ) were found to pose a significantly negative correlation with well-being, demonstrating that respondents reporting higher levels of such elements were more likely to experience higher levels of well-being. Furthermore, the factors of financial stress $(-.529 * *, p$ 
$\leq 0.01)$, family conflict $\left(r=-.285^{* *}, p \leq 0.01\right)$, and stress $\left(r=-.411^{* *}, p \leq 0.01\right)$ were significantly and negatively correlated with well-being, indicated that those with higher levels of such elements showed higher likelihood to experience lower levels of well-being. Pearson's correlation between family dynamics and well-being is shown in Table 2, whereby multiple regression analysis is then utilised to determine the unique predictors of well-being.

Table 2: Pearson's Correlation between Family Dynamics and Well-Being

\begin{tabular}{lll}
\hline Variables & \multicolumn{2}{l}{ Well-Being } \\
\cline { 2 - 3 } & $\mathbf{r}$ & $\mathbf{p}$ \\
\hline Family relationships & $.509^{* *}$ & .000 \\
Family Conflict & $-.285^{* *}$ & .000 \\
Financial Stress & $-.529^{* *}$ & .000 \\
Social Support & $.361^{* *}$ & .000 \\
Stress & $-.411^{* *}$ & .000 \\
\hline
\end{tabular}

Table 3: Summary of Multiple Regression Analysis for Variables Predicting Well-Being

\begin{tabular}{llll}
\hline Variables & Well-Being & & \\
\cline { 2 - 4 } & $\mathbf{B}$ & $\boldsymbol{\beta}$ & .000 \\
\hline Family relationships & .870 & .325 & .001 \\
Family Conflict & .331 & .111 & .000 \\
Financial Stress & -.604 & -.304 & .020 \\
Social Support & .181 & .072 & .000 \\
Stress & -.351 & -.155 & \\
Adjusted $\mathrm{R}^{2}=0.381$ & & & \\
F $=113.486$ & & & \\
\hline
\end{tabular}

\section{Discussion}

The main purpose of this study was to determine the relationship between family dynamics (i.e. family relationships, family conflict, financial stress, social support, and stress) and wellbeing among the Malaysian rural communities. As a result, the outcomes yielded a significantly positive correlation between these variables, which echoed various previous studies. In particular, they have suggested that family relationships may aid a person to cope with stress, engage in healthy behaviours, and increase their self-esteem, thereby leading to enhanced well-being (Thomas et al., 2017). Similarly, the findings parallel older works that have indicated higher satisfaction in life among the people who have better family relationships (Grevenstein et al., 2019).

Furthermore, the study results depicted a significantly positive relationship between social support and well-being, indicating that those with a high level of social support have better well-being. This notion is supported by Siedlecki, Salthouse, Oishi, and Jeswani (2014), whose study has shown a positive association between social support and the elements of happiness and life satisfaction. This may be attributable to its role in improving one's sense of selfefficacy and leading to more understanding, encouragement, respect, courage, and selffulfilment, thereby aiding them in sustaining stable emotions even when they are under stress or pressure (Glozah, 2015). Besides, Feeney and Collins (2014) have attributed social support to better emotion regulation and enhanced positive emotion, which will further improve individual well-being. 
In contrast, the study findings revealed a significantly negative link between financial stress and well-being. This is consistent with the outcomes of Northern, Brien, and Goets (2010), whereby the work has shown that financial stress will influence a person's life, including their relationships and well-being. The findings also showed that family conflict was significantly and negatively correlated with well-being. According to Kader and Roman (2018), a family environment that cannot fulfil the psychological needs that one holds such as relatedness, competence, and autonomy may lead to their inability to satisfy such needs, which are crucial for their psychological well-being development. The need for relatedness has been described by Ryan and Deci (2008) as being cared for and loved by others, along with caring and loving others, which will subsequently create a sense of belonging. Alternatively, competence refers to energising human activity requiring utilisation by people to the best of their abilities whereas autonomy is the chance that one is afforded to make a choice or decision in behavioural regulation (Ryan \& Deci, 2017). Meanwhile, the study findings further depicted the significant and negative correlation between stress and well-being, whereby high levels of stress were found to cause lower levels of well-being. This finding is consistent with the outcomes of Manita et al (2019), which have indicated the significant and negative link between the two variables.

Next, the second objective of this study was to determine the unique predictors of well-being among the rural communities in Malaysia, following which family relationships were found to be the strongest predictor in explaining an individual's well-being. This was followed by financial stress, stress, family conflict, and social support accordingly. In support of the current findings, several past studies have indicated the vital role played by family relationships in developing one's well-being throughout their lifespan (Umberson, Pudrovska, \& Reczek, 2010). According to Hartwell and Benson (2007), the element would provide a greater sense of purpose and meaning along with social and tangible resources, which could be of one's benefit in achieving well-being.

The current study attempted to determine the relationship between family dynamics and the well-being of rural communities in Malaysia during the COVID-19 pandemic. As such, the present findings in this study imply that Kembara Prihatin Negara 2020 programme which has been organized by NPFDB should continue to evolve in line with the needs of local communities living in such locations. This further calls for strengthened prevention efforts at the community level to reduce psychological and psychosocial impact due to the pandemic, such as the provision of psychological services.

However, several key limitations should be highlighted to ensure maximum benefit. First, this study only involved the rural communities that were participating in the FACE Project carried out by NPFDB. Therefore, these findings may not be generalisable to all rural communities in the country, rendering it necessary for future research to investigate family dynamics and well-being in more detail by using more diverse samples and different settings. Moreover, the present study implemented the correlational research design, which disallowed determining the direction of effects between the tested variables. Hence, future studies should include any other statistical analysis in order to find interesting regarding the effect of family dynamics on well-being. Regardless of these limitations, it contributes to the available body of knowledge by enhancing the current understanding of family dynamics, well-being, and their corresponding relationship in the context of Malaysian rural communities during the 
COVID-19 pandemic. Additionally, the findings offer crucial information potentially utilisable in ensuring the development of healthy family relationships among Malaysians to ascertain and enhance their well-being.

\section{Acknowledgement}

This work used a sub set data from a project named Kajian Pandemik COVID-19 dan Perintah Kawalan Pergerakan (PKP): Kesejahteraan Diri dalam Kalangan Komuniti FACE-LPPKN.

\section{Ethical Clearance}

This Ethical Clearance for this project has been approved by the Ethics Committee for Research Involving Human Subjects UPM (JKEUPM) on 19 June 2020 (JKEUPM-2020-158).

\section{References}

Arumugam, T. (2020). MCO-linked domestic violence rises. New Straits Time. Retrieved 5 October, 2020 from https://www.nst.com.my/news/exclusive/2020/04/581233/mco-linked-domesticviolence-rises

Baumeister, R. F., Vohs, K. D., Aaker, J. L., \& Garbinsky, E. N. (2013). Some key differences between a happy life and a meaningful life. The Journal of Positive Psychology, 8(6), 505-516.

Boudreau, M., Gefen, D., \& Straub, D. (2001). Validation in IS research: A state-of-the-art assessment. MIS Quarterly, 25, 1-24. https://doi.org/10.2307/3250956

Cohen, S. (2004). Social relationships and health. American Psychologist, 59(8), 676-684. https://doi.org/10.1037/0003-066X.59.8.676

Dai, H., Zhang, S. X., Looi, K. H., Su, R., \& Li, J. (2020). Perception of health conditions and test availability as predictors of adults' mental health during the COVID-19 pandemic: A survey study of adults in Malaysia. International Journal of Environmental Research and Public Health, 17, 5498.

Davis, C. G., \& Mantler, J. (2004). The consequences of financial stress for individuals, families and society. Ottawa, ON: Doyle Salewski Inc.

Department of Statistics Malaysia. (2020). Laporan survei khas kesan COVID-19 kepada ekonomi dan individu (Pusingan 1). Retrieved October 2, 2020, from https://www.dosm.gov.my/v1/uploads/files/covid-

19/Analisis_Survei_Khas_Kesan_COVID-19_Kepada_Ekonomi_dan_IndividuLaporan_Penuh.pdf

Diener, E., Scollon, C. N., \& Lucas, R. E. (2009). The evolving concept of subjective well-being: The multifaceted nature of happiness. Social Indicators Research Series, 39, 67-99. https://doi.org/10.1016/S1566-3124(03)15007-9

Feeney, B. C., \& Collins, N. L. (2014). A new look at social support: A theoretical perspective on thriving through relationships. Personality and Social Psychology Review, 19, 113147. https://doi.org/10.1177/1088868314544222

Glozah, F. N. (2015). Exploring Ghanaian adolescents' meaning of health and well-being: A psychosocial perspective. International Journal of Qualitative Studies on Health and Well-Being, 10(1), 1-10. https://doi.org/10.3402/qhw.v10.26370

Grevenstein, D., Schweitzer, J., \& Aguilar-Raab, C. (2019). How children and adolescents evaluate their families: Psychometric properties and factor structure of the evaluation 
of social systems (EVOS) scale. Journal of Child and Family Studies, 28(17), 17-29. https://doi.org/10.1007/s10826-018-1254-6

Gunn, H. E., \& Eberhardt, K. R. (2019). Family dynamics in sleep health and hypertension. Current Hypertension Reports, 21(39), 1-23. https://doi.org/10.1007/s11906-0190944-9

Habib, C., Toumbourou, J. W., Mcritchie, M., Williams, J., Kremer, P., Mckenzie, D., \& Catalano, R. F. (2014). Prevelance and community variation in harmful levels of family conflict witnessed by children: Implications for prevention. Prevention Science, 15, 757-766.

Hartwell, S. W., \& Benson, P. R. (2007). Social integration: A conceptual overview and two case studies. In W. R. Avison, J. D. McLeod, \& B. Pescosolido (Eds.). Mental health, social mirror (pp. 329-353). Springer.

Helliwell, J. F., Layard, R., \& Sachs, J. (Eds.). (2016). World happiness report 2016. Sustainable Development Solutions Network.

Henry, C. S., Morris, A. S., \& Harrist, A. W. (2015). Family resilience: Moving into the third wave. Family Relations, 64(1), 22-43. https://doi.org/10.1111/fare.12106

Infurna, F. J., \& Luthar, S. S. (2016). Resilience to major life stressors is not as common as thought. Perspectives on Psychological Science, 11(2), 175-194. https://doi. org/10.1177/1745691615621271

Jabbari, B., \& Rouster, A. S. (2020). Family Dynamics. Retreived 4 October, 2020, from https://www.ncbi.nlm.nih.gov/books/NBK560487/

Jacobson, N. C., Lord, K. A., \& Newman, M. G. (2017). Perceived emotional social support in bereaved spouses mediates the relationship between anxiety and depression. Journal of Affect Disorder, 211, 83-91.

Kader, Z., \& Roman, N. (2018). The effects of family conflict on the psychological needs and externalising behaviour of preadolescents. Social Work, 54(1), 37-52. http://dx.doi.org/10.15270/54-1-613

Kaniasty, K., \& Norris, F. H. (2008). Longitudinal linkages between perceived social support and posttraumatic stress symptoms: Sequential roles of social causation and social selection. Journal of Traumatic Stress, 21, 274-281. https://doi.org/10.1002/jts

Landstedt, E., Hammarström, A., \& Winefield, H. (2015). How well do parental and peer relationships in adolescence predict health in adulthood. Scandinavian Journal of Public Health, 43(5), 460-468. https://doi.org/10.1177/1403494815576360.

Lewis, B. R., Snyder, C. A., \& Rainer, K. R. (1995). An empirical assessment of the Information Resources Management construct. Journal of Management Information Systems, 12, 199-223.

Lincoln, K. D. (2014). Social relationships and health among minority older adults. In K. E. Whitfield, \& T. A. Baker (Eds.), Handbook of minority aging (pp. 25-46). Springer.

Lovibond, S. H., \& Lovibond, P. F. (1995). Manual for the Depression Anxiety and Stress Scales $\left(2^{\text {nd }}\right.$ ed.). Psychology Foundation.

Manita, E., Mawarpury, M., Khairani, M., \& Sari, K. (2019). Hubungan stres dan kesejahteraan (well-being) dengan moderasi kebersyukuran. Gadjah Mada Journal of Psychology, 5(2), 178-186.

Marta, E., \& Alfieri, S. (2014). Family conflicts. In A. C. Michalos (Ed.). Encyclopedia of Quality of Life and Well-being Research. Springer, Dordecht. Dou:

https://doi.org/10.1007/978-94-007-0753-5. 
Merz, E. M., Consedine, N. S., Schulze, H. J., \& Schuengel, C. (2009). Well-being of adult children and ageing parents: Associations with intergenerational support and relationship quality. Ageing and Society, 29, 783-802.

Mikuska, E. (2017). The importance of piloting or pre-testing semi-structured interviews and narratives. SAGE Research Methods Cases. https://doi.org/10.4135/9781473977754

Nadzir, M. S., Ooi, M. C. G., Alhasa, K. M., Bakar, M. A. A., Mohtar, A. A. A., Nor, M. F. F. M., Latif, M. T., Hamid, H. H. A., Ali, S. H. M., Ariff, N. M., Anuar, J., Ahamad, F., Azhari, A., Hanif, N. M., Subhi, M. A., Othman, M., \& Nor, M. Z. M. (2020). The impact of Movement Control Order (MCO) during pandemic COVID-19 on local air quality in an urban area of Klang Valley, Malaysia. Aerosol and Air Quality Research, 20, 12371248. https://doi.org/10.4209/aaqr.2020.04.0163

Muhammad, S., Long, X., \& Salman, M. (2020). COVID-19 pandemic and environmental pollution: A blessing in disguise? Science of the total environment, 728, 1-5.

Nothern, J., O'Brien, W. H., \& Goetz, P. W. (2010). The development, evaluation, and validation of a financial stress scale for undergraduate students. Journal of College Student Development, 51(1), 79-92.

Number of people losing jobs doubling every month since start of MCO (2020, 21 July). Malaysia Kini. Retrieved 10 October, 2020, from https://www.malaysiakini.com/news/535391

Perissinotto, C. M., Cenzer, I. S., \& Covinsky, K. E. (2012). Loneliness in older persons. JAMA Internal Medicine, 172(14), 1078-1084.

Prawitz, A. D., Garman, E. T., Sorhaindo, B., O’Neill, B., Kim, J., \& Drentea, P. (2006). Incharge financial distress/financial well-being scale: Development, administration, and score inrepretation. Financial Counseling and Planning, 17, 34-50.

Prime, H., Wade, W., \& Browne, D. T. (2020). The risk and resilience in family well-being during the COVID-19 pandemic, American Psychologist, 75(5), 631-643. http://dx.doi.org/10.1037/amp0000660

Ratnasingam, J. (2020). Socio-economic impact of the COVID-19 pandemic on the woodbased industry in Malaysia (IFRG Report. No. 6/SP), International Furniture Research Group, Singapore.

Robbins, S. P., Judge, T. A., \& Vohra, N. (2013). Organisational behavior (15th ed.). Delhi: Pearson Education, Inc.

Ryan, R. M., \& Deci, E. L. (2001). On happiness and human potentials: A review of research on hedonic and eudaimonic well-being. Annual Review of Psychology, 52,141-66. http://dx.doi.org/10.1146/annurev.psych.52.1.141

Ryan, R. M., \& Deci, E. L. (2008) Self-determination theory and the role of basic psychological needs in personality and the organisation of behavior. In O. P. John, R. W. Robbins, \& L. A. Pervin (Eds.). Handbook of personality: Theory and research (pp 654-678). Guilford Press.

Ryan, R. M., \& Deci, E. L. (2017). Self-determination theory: Basic Psychological Needs in Motivation, Development, and Wellness. Guilford Publications.

Saltzman, L. Y., Hansel, T. C., \& Bordnick, P. S. (2020). Loneliness, isolation, and social support factors in post-COVID-19 mental health. American Psychological Association, 12(1), 55-S57. http://dx.doi.org/10.1037/tra0000703

Seligman, M. E. P. (2011). Flourish: A Visionary New Understanding of Happiness and WellBeing. Free Press. 
Shakeel, S., Hassali, M. A. A., \& Naqvi, A. A. (2020). Health and economic impact of COVID-19: mapping the consequences of a pandemic in Malaysia. Malaysian Journal of Medical Sciences, 27(2), 159-164.

Siedlecki, K. L., Salthouse, T. A., Oishi, S., \& Jeswani, S. (2014). The relationship between social support and subjective well-being across age. Social Indicators Research, 117, 561576. https://doi.org/10.1007/a11205-013-0361-4

Taherdoost, H. (2016). Sampling methods in research methodology: How to choose a sampling technique for research. International Journal of Advance Research in Management, 5(2), 18-27.

Thomas, P. A., Liu, H., \& Umberson, D. (2017). Family relationships and well-being. Innovation in Aging, 1(3), 1-11. https://doi.org/10.1093/geroni/igx025

Tov, W. (2018). Well-being Concepts and Components. In E. Diener, S. Oishi, \& L. Tay (Eds.), Handbook of well-being. DEF Publishers.

Uchino, B. N. (2006). Social support and health: A review of physiological processes potentially underlying links to disease outcomes. Journal of Behavioral Medicine, 29(4), 377-387. https://doi.org/10.1007/s10865-006-9056-5.

Umberson, D., Crosnoe, R., \& Reczek, C. (2010). Social relationships and health behavior across the life course. Annual Review of Sociology, 36(36) 139-157. https://doi.org/10.1146/annurev-soc-070308-120011

Umberson, D., Pudrovska, T., \& Reczek, C. (2010). Parenthood, childlessness, and well-being: A lifecourse perspective. Journal of Marriage and Family, 72(3), 612- 629.

Widmer, E. D. (2010). Family configurations. A structural approach to family adversity. Ashgate Publishing. 